\title{
A New Oral Isotopic Test of Calcium Absorption *
}

\author{
Louis V. Avioli, Joseph E. McDonald, Richard A. Singer, and Philip H. \\ Henneman With the technical assistance of Sook Won Lee and \\ Erika Hessman
}

\author{
(From the Division of Endocrinology, Department of Medicine, Seton Hall College of \\ Medicine, Jersey City, N. J.)
}

\begin{abstract}
Abnormal absorption of dietary calcium has been recognized for many years in intestinal diseases, sarcoidosis (1), idiopathic hypercalciuria (2), hypoparathyroidism $(3,4)$, hyperparathyroidism (5-7), and more recently in calcinosis universalis (8). Understanding of calcium absorption in the past has been limited by the requirement of 18 to 20 days of metabolic balance procedures; interpretation has been limited by the paucity of data in normal subjects. This paper describes a safe and simple 4-hour isotopic test of calcium absorption that has been evaluated statistically in 21 normal subjects and in 31 patients with disorders known to alter calcium absorption.
\end{abstract}

\section{Methods}

Twenty-one normal subjects (average age, 36; range, 21 to 65 years) and 31 patients (average age, 44 ; range, 14 to 73 years) with disorders likely to alter calcium absorption were studied. The latter group consisted of 14 patients with disorders characterized by decreased intestinal absorption (hypoparathyroidism, celiac disease, postsurgical malabsorption, regional ileitis, and calcific pancreatitis with insufficiency) and 17 patients with disorders characterized by increased calcium absorption (hyperparathyroidism, sarcoidosis, idiopathic hypercalciuria, and calcinosis universalis). The diagnoses of intestinal malabsorption were established by the presence of steatorrhea, diminished $\mathbf{D}$-xylose absorption, abnormal small bowel series, and salutary response to a gluten-free diet in the patients with celiac disease. The clinical diagnoses of hyperparathyroidism and sarcoidosis were confirmed histopathologically. One patient (A.D.) with tetany, hypocalcemia, and hyperphosphatemia was found to have idiopathic hypoparathyroidism. Patients with normal serum calcium, decreased serum phos-

* Submitted for publication March 23, 1964 ; accepted September 24, 1964.

Supported in part by grants from the U. S. Public Health Service (Clinical Research Center grant FR-41, National Institute of Arthritis and Metabolic Diseases grant 06404, and trainee grant 2A-5211) and Atomic Energy Commission contract AT(30-1)-3174. phorus, hypercalciuria that varied with calcium intake, and recurrent calcium stones were classified as having idiopathic hypercalciuria.

Twenty-four individuals were studied under metabolic balance conditions and 30 during routine ward or outpatient admissions. Calcium intake in all subjects was either known or was estimated by detailed dietary survey to range from 175 to $1,100 \mathrm{mg}$ per day.

At the end of the customary 12- to 15-hour overnight fast, and 1 hour before breakfast, 5 to $10 \mu \mathrm{c}$ of $\mathrm{Ca}^{47} \mathrm{Cl}_{2}$ (SA greater than $150 \mathrm{mc}$ per $\mathrm{g}$ calcium) was administered orally in $5 \mathrm{ml}$ of distilled water containing $20 \mathrm{mg}$ of calcium as $\mathrm{CaCl}_{2}$. During the following 4-hour period the patients were hydrated to insure a urine flow of 2 to $4 \mathrm{ml}$ per minute. Venous blood was obtained for stable serum calcium measurement before the oral $\mathrm{Ca}^{47}$ and for radioactivity measurements at 15-minute intervals for the first hour following the oral dose and at hourly intervals for the subsequent 3 hours. Urine was collected in two 2-hour periods during the 4-hour test period. Six-day stool collections following the oral dose were obtained in 27 patients. Stable calcium in plasma and urine was determined with a flame-spectrophotometric technique (9) (normal serum values range from 8.5 to $10.5 \mathrm{mg}$ per $100 \mathrm{ml}$ ). Serum inorganic phosphorus determinations were made according to the method of Fiske and SubbaRow (10) (normal values range from 3.0 to $4.5 \mathrm{mg}$ per $100 \mathrm{ml}$ ). $\mathrm{Ca}^{47}$ determinations were performed on $5 \mathrm{ml}$ of plasma, on $20-\mathrm{ml}$ samples of each 2-hour collection, and on 200-ml samples of 6-day fecal homogenates in a well-type scintillation counter utilizing pulse-height spectrometric analysis. Discriminator settings were selected to give optimal statistical accuracy with a counting error no greater than $1 \%$. Energies below $400 \mathrm{kev}$ were eliminated by a single-channel gammaray spectrometer to exclude the gamma emission of scandium $^{47}$. In each instance samples of the administered $\mathrm{Ca}^{47}$ test dose were also counted under identical geometric conditions, and the radioactivity of the plasma was expressed as per cent of administered dose per liter of plasma. Urine and stool radioactivity was expressed as per cent of administered dose.

\section{Results}

Normal subjects. Plasma, urinary, and fecal $\mathrm{Ca}^{47}$ content in the 21 normal subjects is shown 


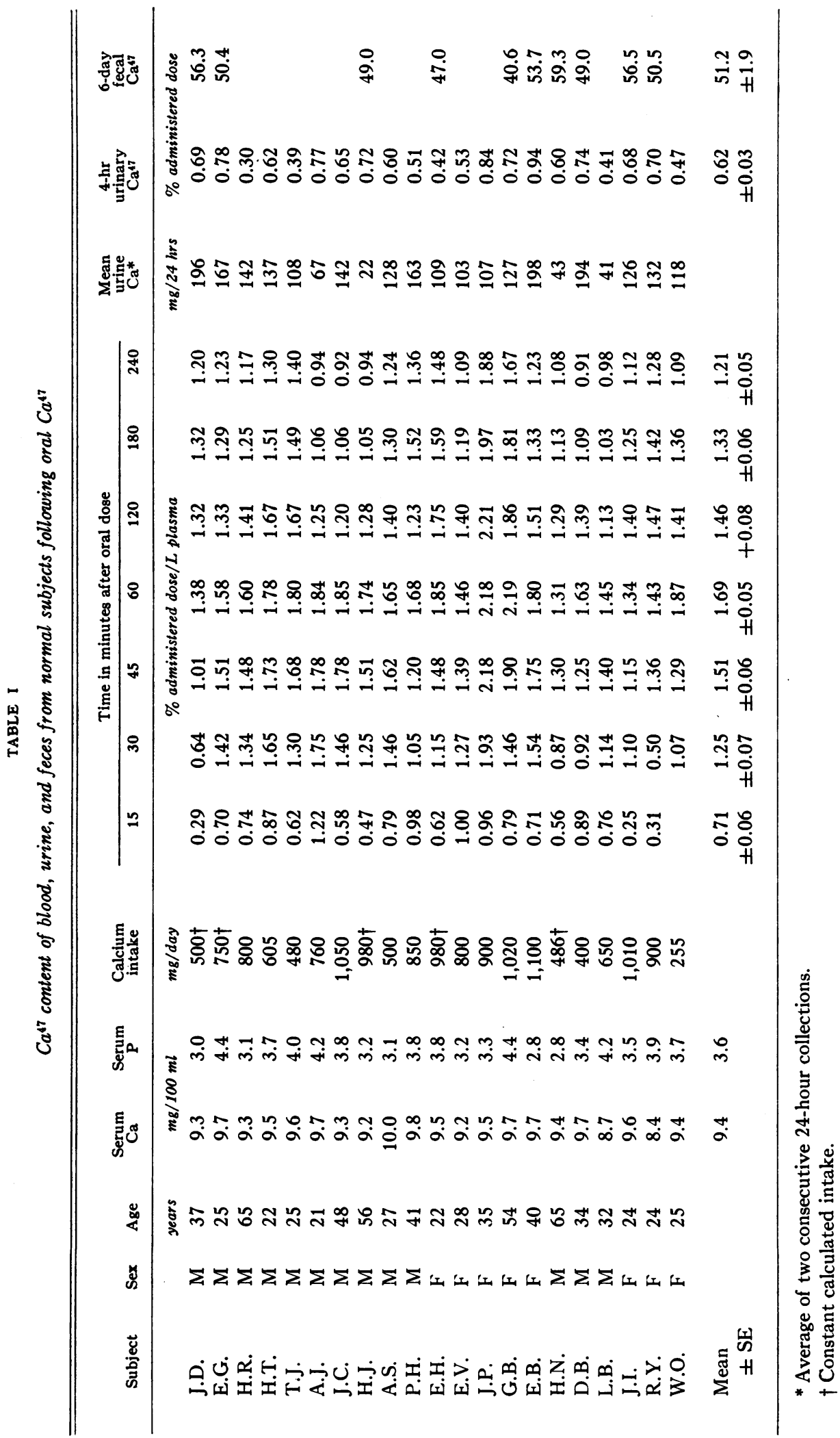




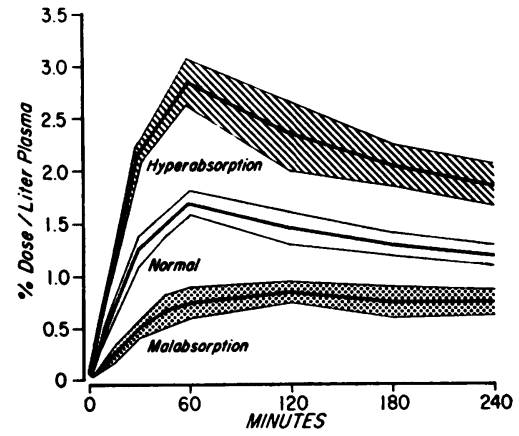

Fig. 1. Four-hour plasma $\mathrm{CA}^{47}$ abSORPTION IN 21 NORMAL SUBJECTS AND IN 31 PATIENTS WITH MALABSORPTIVE AND HYPERABSORPTIVE DEFECTS. In each group the shaded area represents $2 \mathrm{SE}$ below and above the population mean represented by the dark line.

in Table I and Figure 1. In each normal subject given $\mathrm{Ca}^{47}$, increments in blood radioactivity were observed for the first hour followed by a gradual decline during the subsequent 3-hour period. The average plasma value at 1 hour was 1.69 (range, 1.31 to 2.19 ) $\%$ of the dose per L plasma. Serum calcium concentrations in the fasting subjects ranged from 8.4 to $10.0 \mathrm{mg}$ per $100 \mathrm{ml}$, and no significant change was observed during the 4-hour test period. The average 4-hour cumulative urinary radioactivity was 0.62 (range, 0.30 to 0.94 ) \% of the administered dose. The average 6-day fecal excretion of radioactive calcium in ten normal subjects was 51.2 (range, 40.6 to 59.3 ) $\%$ of the dose.

Increased calcium absorption. The results in 17 patients with disorders in which increased calcium absorption has been previously identified are recorded in Table II and depicted in Figure 1. In this group the normal pattern was exaggerated; six of the 17 patients reached peak $\mathrm{Ca}^{47}$ levels at 45 minutes. Peak values at 45 to 60 minutes were followed by a gradual decline during the ensuing 3 hours (Figure 1). The average 1-hour plasma value was 2.85 (range, 1.94 to 3.94 ) \% dose per L. All the timed plasma radioactivity values (except those at 15 minutes) during the 4-hour test period were significantly higher than those in the normal subjects $(p<0.001)$. Fifteen patients in this group had normal serum calcium concentrations despite abnormally high 1-hour plasma radioactive calcium levels (Figure 2). Both patients with hyperparathyroidism (J.G. and H.G., Table II) had hypercalcemia, but a significant elevation in plasma $\mathrm{Ca}^{47}$ was observed in only one (J.G.). Cumulative 4-hour urinary $\mathrm{Ca}^{47}$ was generally greater than normal in the entire group, with an average value of 1.38 (range, 0.85 to 2.53 ) $\%$ of the dose. This correlates well with the hypercalciuria frequently found in patients with increased intestinal absorption. Six-day fecal radioactivity determinations in six of these patients averaged 32.4 (range, 23.8 to 38.7 ) \% of the administered dose and were lower than all of the 6-day fecal $\mathrm{Ca}^{47}$ values in the normal subjects.

Decreased calcium absorption. The results in 14 patients with disorders in which decreased calcium absorption has been previously identified are recorded in Table III. The rate of increase in plasma radioactivity was much slower than in the normal subjects (Figure 1). Peak values were delayed until 2 hours after administration of the dose, and only a slight decline in radioactivity occurred during the subsequent 2-hour period. The mean plasma $\mathrm{Ca}^{47}$ levels at each time interval were significantly lower than those in normal subjects. Despite low 1-hour plasma radioactivity values (average, 0.80 ; range, 0.34 to $1.10 \%$ dose per L, serum calcium concentration was normal in nine of the 14 patients studied (Figure 2). Hypocalcemia was prominent in L.P., a patient with

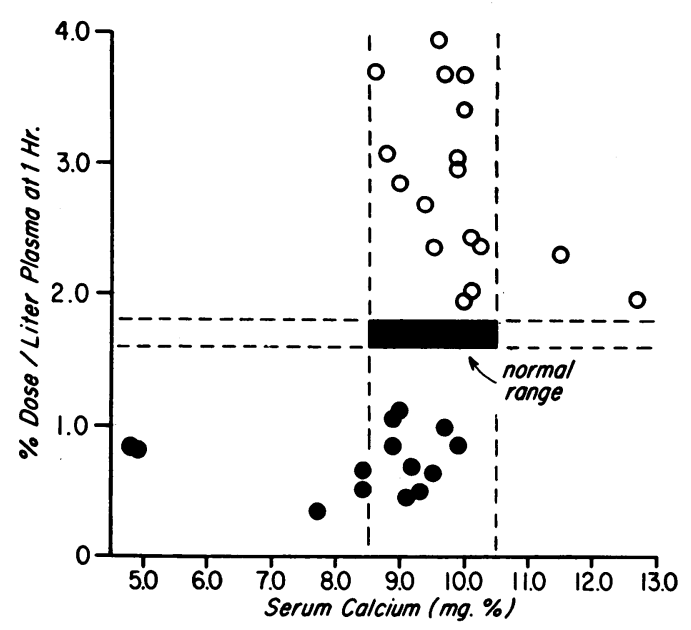

Fig. 2. Relation of 1-hour plasma CA ${ }^{47}$ concentraTION TO SERUM STABLE CALCIUM IN 31 PATIENTS With ABNORMAL CALCIUM ABSORPTION. The horizontal dotted lines represent $2 \mathrm{SE}$ below and above the normal mean 1-hour $\mathrm{Ca}^{47}$ level. The vertical dotted lines outline the normal serum calcium range of 8.5 to $10.5 \mathrm{mg}$ per 100 $\mathrm{ml}$. Open and closed circles represent values obtained in hyper- and hypoabsorptive disorders, respectively. 
ISOTOPIC TEST OF CALCIUM ABSORPTION

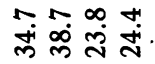

峞芦

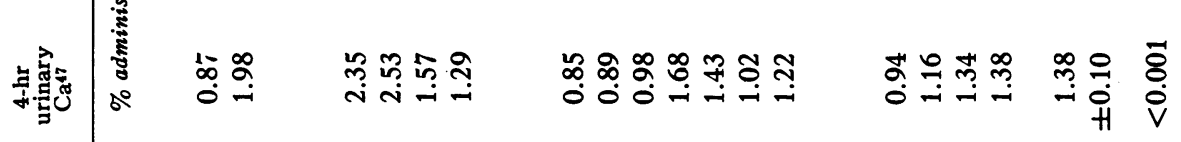

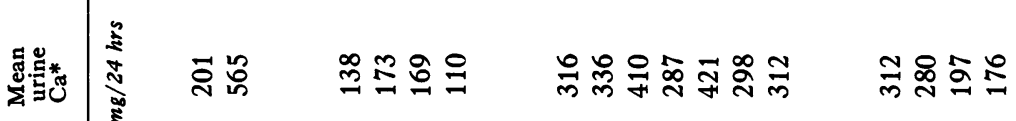

कै

|

$\stackrel{m}{\dddot{2}}$

สฺุ

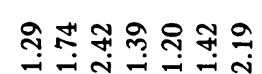

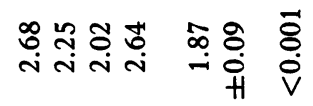

ชั

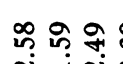

马ํำ

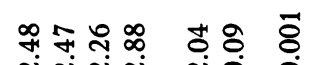
iัi

莺

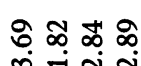

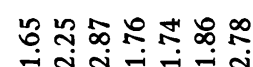

-

范 (1)

กัa

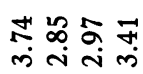

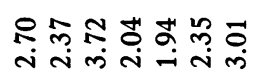

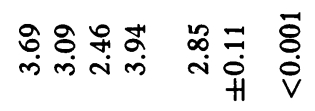

సิํำ

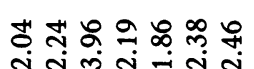

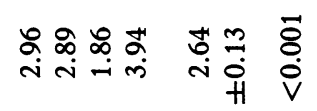

ํํำ

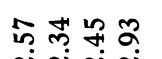

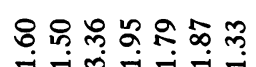

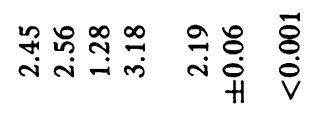

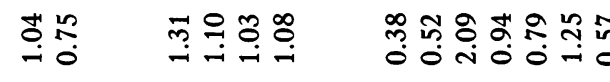

$$
\text { 要品芯 }
$$

U.

密

mo

nก ำ

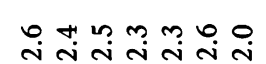

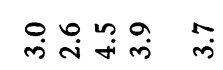

हूँ

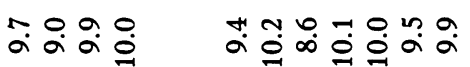

$\because \stackrel{0}{\infty}=000$

$\stackrel{8}{4}$

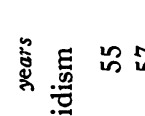

5

竞 $\Sigma$

ำ ํำล

.

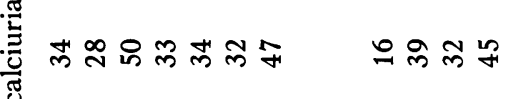

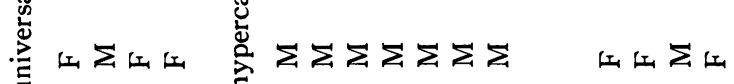

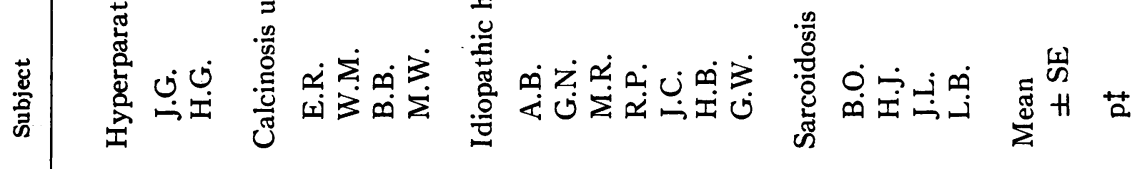




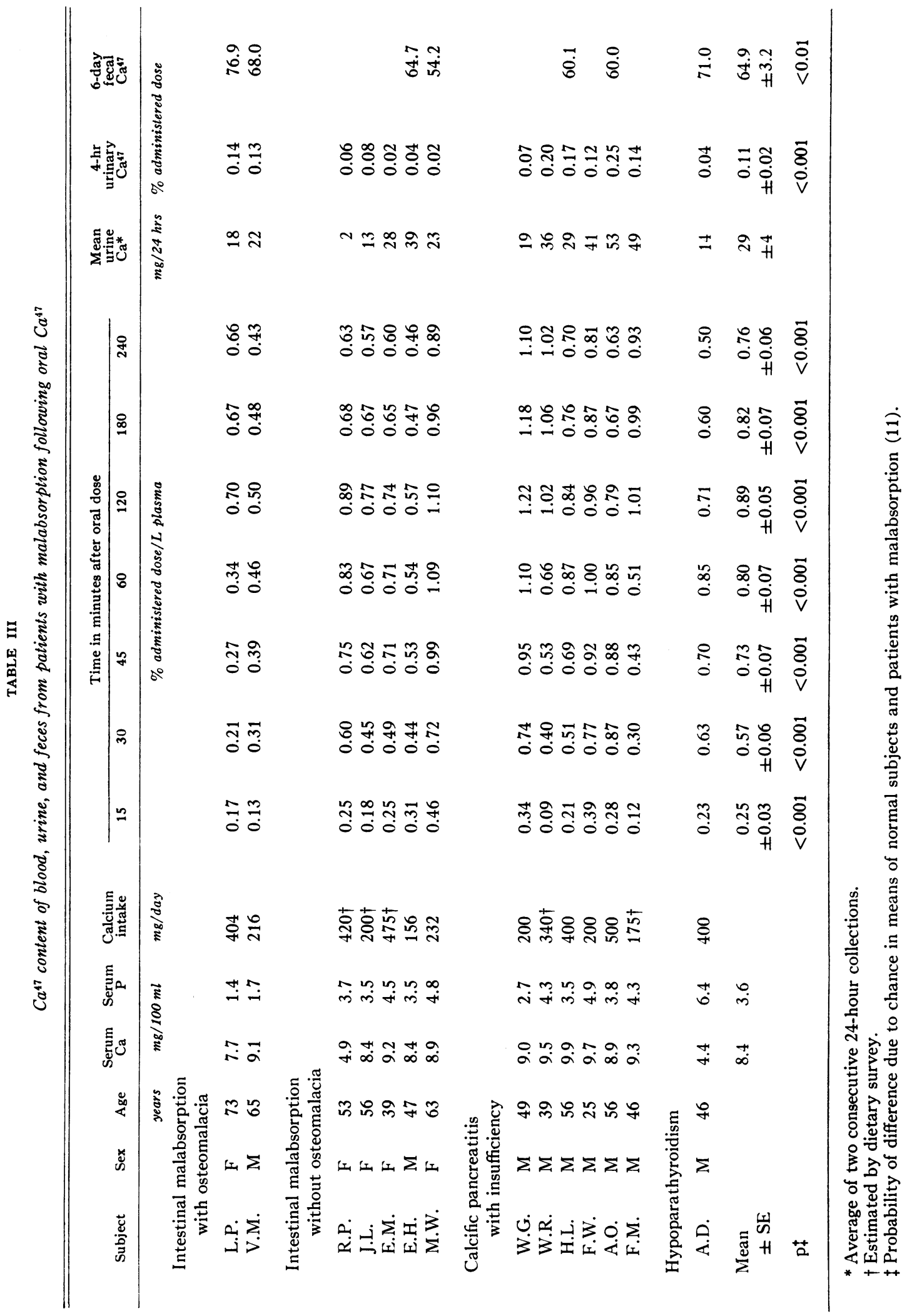


severe celiac disease and osteomalacia, in R.P. with marked steatorrhea consequent to gastrectomy and partial ileectomy, and in A.D. with idiopathic hypoparathyroidism (Table III). In subjects with malabsorption the mean 4-hour urinary radioac tivity of 0.11 (range, 0.02 to 0.25 ) \% adminis. tered dose was notably less than normal and reflected the low urinary stable calcium excretion. Cumulative 6-day stool excretion of $\mathrm{Ca}^{47}$ in seven patients averaged 64.9 (range, 54.2 to 76.9) \% of the administered dose with only one value within the normal range.

Reproducibility of test. The oral $\mathrm{Ca}^{47}$ test was repeated two times in two subjects (J.D., L.P.) and three times in another (B.B.) during the constant conditions of balance studies with good reproducibility of both plasma and fecal $\mathrm{Ca}^{47}$ values (Table IV).

Effects of therapy. Sodium phytate decreases calcium absorption in patients with sarcoidosis

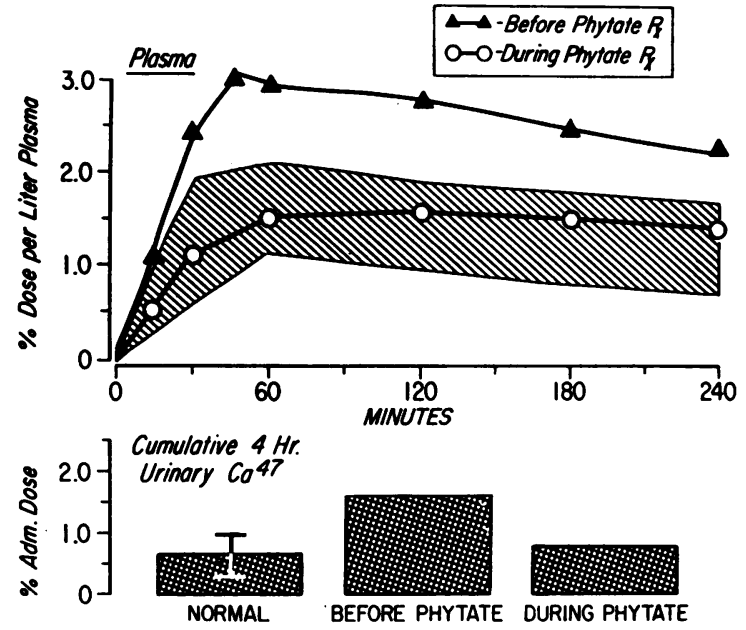

Fig. 3. Serial $\mathrm{CA}^{47}$ ORAL tests in B.B., A Patient WITH CALCINOSIS UNIVERSALIS, BEFORE AND DURING SODIUM PHYTATE THERAPY. The shaded area represents $2 \mathrm{SD}$ below and above the mean normal values. The normal cumulative 4-hour urinary $\mathrm{Ca}^{47}$ is represented by the mean and range of the 21 subjects in Table I.

TABLE IV

Reproducibility of oral $\mathrm{Ca}^{47}$ test and effects of therapy

\begin{tabular}{|c|c|c|c|c|c|}
\hline Subject & $\mathrm{Ca}$ intake & Date of test & Treatment & Plasma Ca ${ }^{47}$ & $\underset{\text { fecal Ca*t }}{\text { 6-day }}$ \\
\hline & $m g / d a y$ & & & $\begin{array}{c}\% \text { dose } / L \\
\text { at } 1 \mathrm{hr}\end{array}$ & $\%$ dose \\
\hline J.D. (normal) & $\begin{array}{r}500 \\
500 \\
1,035 \\
1,035\end{array}$ & $\begin{array}{r}6 / 28 / 63 \\
12 / 21 / 63 \\
1 / 9 / 64 \\
2 / 6 / 64\end{array}$ & $\begin{array}{l}\text { None } \\
\text { None } \\
\text { None } \\
50,000 \text { U vitamin } \\
\mathrm{D}_{2} \text { daily for } 3 \\
\text { weeks }\end{array}$ & $\begin{array}{l}1.38 \\
1.36 \\
0.94 \\
2.14\end{array}$ & $\begin{array}{l}56.3 \\
57.5 \\
58.2 \\
40.8\end{array}$ \\
\hline $\begin{array}{l}\text { B.B. (calcinosis } \\
\text { universalis) }\end{array}$ & $\begin{array}{l}225 \\
225 \\
200 \\
200\end{array}$ & $\begin{array}{r}7 / 15 / 63 \\
7 / 26 / 63 \\
11 / 17 / 63 \\
11 / 29 / 63\end{array}$ & $\begin{array}{c}\text { None } \\
\text { None } \\
\text { None } \\
\text { Sodium phytate } \\
3.0 \mathrm{~g}, 3 \text { times } \\
\text { daily with meals }\end{array}$ & $\begin{array}{l}2.83 \\
2.74 \\
2.97 \\
1.28\end{array}$ & $\begin{array}{l}24.2 \\
22.6 \\
23.8 \\
49.0\end{array}$ \\
\hline $\begin{array}{l}\text { L.P. (osteomalacia } \\
\text { and celiac disease) }\end{array}$ & $\begin{array}{l}404 \\
404 \\
404\end{array}$ & $\begin{array}{r}7 / 11 / 63 \\
8 / 12 / 63 \\
12 / 11 / 63\end{array}$ & $\begin{array}{c}\text { None } \\
\text { None } \\
50,00 \text { U vitamin } \\
\mathrm{D}_{2} \text { daily for } 2 \\
\text { months }\end{array}$ & $\begin{array}{l}0.34 \\
0.48 \\
2.63\end{array}$ & $\begin{array}{l}76.9 \\
74.3 \\
25.8\end{array}$ \\
\hline $\begin{array}{l}\text { M.W. (intestinal } \\
\text { malabsorption) }\end{array}$ & $\begin{array}{l}232 \\
232\end{array}$ & $\begin{array}{l}1 / 9 / 64 \\
1 / 28 / 64\end{array}$ & $\begin{array}{l}\text { None } \\
50,000 \text { U vitamin } \\
\mathrm{D}_{2} \text { daily for } 14 \\
\text { days }\end{array}$ & $\begin{array}{l}1.09 \\
2.50\end{array}$ & $\begin{array}{l}54.2 \\
14.5\end{array}$ \\
\hline \multirow[t]{2}{*}{$\begin{array}{l}\text { V.M. (osteomalacia } \\
\text { with selective } \\
\text { calcium malabsorp- } \\
\text { tion) }\end{array}$} & $\begin{array}{r}216 \\
1,000\end{array}$ & $\begin{array}{r}11 / 5 / 62 \\
4 / 9 / 63\end{array}$ & $\begin{array}{l}\text { None } \\
300,000 \text { U vitamin } \\
\mathrm{D}_{2} \text { daily for } 30 \\
\text { days }\end{array}$ & $\begin{array}{l}0.46 \\
2.18\end{array}$ & $\begin{array}{l}68.0 \\
23.5\end{array}$ \\
\hline & $\begin{array}{l}1,000 \\
1,000 \\
1,000 \\
1,000\end{array}$ & $\begin{array}{l}5 / 5 / 63 \\
9 / 18 / 63 \\
1 / 3 / 64 \\
1 / 23 / 64\end{array}$ & $\begin{array}{l}\text { None } \\
\text { None } \\
\text { None } \\
\text { None }\end{array}$ & $\begin{array}{l}1.80 \\
1.42 \\
0.94 \\
1.02\end{array}$ & $\begin{array}{l}42.0 \\
49.0 \\
52.2 \\
51.8\end{array}$ \\
\hline
\end{tabular}


TABLE V

$\mathrm{Ca}^{47}$ content of serum in hyperabsorptive disorders and the results of sodium phytate therapy

\begin{tabular}{|c|c|c|c|c|c|c|c|c|c|c|}
\hline \multirow[b]{2}{*}{ Subject } & \multirow[b]{2}{*}{ Diagnosis } & \multicolumn{7}{|c|}{ Time in minutes after oral dose } & \multirow{2}{*}{$\underset{\substack{\text { urinary } \\
\mathrm{Ca}^{47}}}{\text { 4hr }}$} & \multirow{2}{*}{$\begin{array}{l}\text { 6-day } \\
\text { fecal } \\
\mathrm{Ca}^{47}\end{array}$} \\
\hline & & 15 & 30 & 45 & 60 & 120 & 180 & $\overline{240}$ & & \\
\hline & & \multicolumn{7}{|c|}{$\%$ administered dose $/ L$ plasma } & \multicolumn{2}{|c|}{$\%$ administered dose } \\
\hline M.W. & \multirow{2}{*}{$\begin{array}{l}\text { Metastatic cal- } \\
\text { cification }\end{array}$} & 1.08 & 2.93 & 3.03 & 3.41 & 2.89 & 2.39 & 2.23 & 1.29 & 24.4 \\
\hline M.W.* & & 0.12 & 0.28 & 0.62 & 0.77 & 0.91 & 0.92 & 0.83 & 0.04 & 70.2 \\
\hline A.D. & \multirow{2}{*}{$\begin{array}{l}\text { Metastatic cal- } \\
\text { cification }\end{array}$} & 2.81 & 5.29 & 7.04 & 7.96 & 6.01 & 5.29 & 4.39 & 0.53 & 18.0 \\
\hline A.D.* & & 0.35 & 1.00 & 1.54 & 1.97 & 3.18 & 2.60 & 2.33 & 0.23 & 54.0 \\
\hline B.B. & \multirow{2}{*}{$\begin{array}{l}\text { Metastatic cal- } \\
\text { cification }\end{array}$} & 1.03 & 2.45 & 3.05 & 2.97 & 2.84 & 2.49 & 2.25 & 1.57 & 23.8 \\
\hline B.B.* & & 0.89 & 1.08 & 1.21 & 1.28 & 1.32 & 1.37 & 1.28 & 0.77 & 61.0 \\
\hline R.P. & \multirow{2}{*}{$\begin{array}{l}\text { Idiopathic hyper- } \\
\text { calciuria }\end{array}$} & 0.94 & 1.95 & 2.19 & 2.04 & 1.76 & 1.51 & 1.39 & 1.68 & \\
\hline R.P.* & & 0.37 & 0.43 & 0.76 & 0.84 & 0.90 & 0.85 & 0.83 & 0.41 & \\
\hline G.N. & \multirow{2}{*}{$\begin{array}{l}\text { Idiopathic hyper- } \\
\text { calciuria }\end{array}$} & 0.52 & 1.50 & 2.24 & 2.37 & 2.25 & 1.87 & 1.74 & 0.89 & \\
\hline G.N.* & & 0.21 & 0.49 & 0.57 & 0.68 & 0.71 & 0.64 & 0.61 & 0.14 & \\
\hline $\begin{array}{l}\text { L.B. } \\
\text { L.B.* }\end{array}$ & Sarcoidosis & $\begin{array}{l}0.74 \\
0.29\end{array}$ & $\begin{array}{l}3.18 \\
0.44\end{array}$ & $\begin{array}{l}3.94 \\
0.63\end{array}$ & $\begin{array}{l}3.94 \\
0.75\end{array}$ & $\begin{array}{l}3.22 \\
0.87\end{array}$ & $\begin{array}{l}2.88 \\
0.82\end{array}$ & $\begin{array}{l}2.64 \\
0.78\end{array}$ & $\begin{array}{l}1.38 \\
0.51\end{array}$ & $\begin{array}{l}38.4 \\
57.3\end{array}$ \\
\hline
\end{tabular}

* Repeat oral $\mathrm{Ca}^{47}$ test during sodium phytate therapy.

(1), idiopathic hypercalciuria (2), and calcinosis universalis (8). The simultaneous administration of phytate and $\mathrm{Ca}^{47}$ to patient B.B. during a balance study resulted in markedly decreased plasma and increased fecal $\mathrm{Ca}^{47}$ values (Table IV, Figure 3). Similar documentation of decreased calcium absorption by sodium phytate during the proposed 4-hour $\mathrm{Ca}^{47}$ oral test has been made in five other patients with sarcoidosis, idiopathic hypercalciuria, and calcinosis universalis (Table V).

Vitamin D increased plasma and decreased fecal $\mathrm{Ca}^{47}$ in patients J.D., L.P., M.W., and V.M. during metabolic balance studies (Table IV). Serial

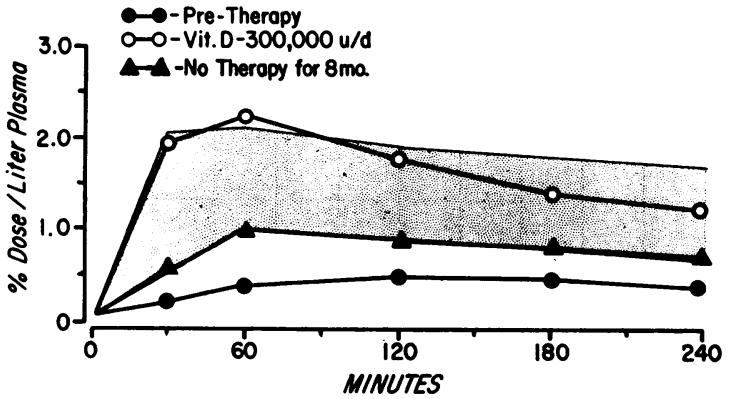

Fig. 4. Serial CA ${ }^{47}$ oral tests in V.M., a patient WITH OSTEOMALACIA, BEFORE, DURING, AND AFTER CESSATION OF VITAMIN D THERAPY. The shaded area represents $2 \mathrm{SD}$ below and above the mean normal curve. studies on J.D. were of interest, since the effect of dietary calcium increments on calcium absorption is demonstrated as well as the effect of vitamin D. During a metabolic balance period wherein J.D. received $500 \mathrm{mg}$ calcium daily, the results of two oral $\mathrm{Ca}^{47}$ tests were remarkably consistent (1-hour plasma values of 1.36 and $1.38 \%$ dose per L plasma). A third absorption test subsequently obtained when calcium intake had been increased to $1,035 \mathrm{mg}$ per day demonstrated a significant decrease in absorption (Table IV). In V.M. vitamin D therapy was discontinued in April 1963 because of apparent cure of osteomalacia and occurrence of hypercalcemia. Serial oral $\mathrm{Ca}^{47}$ tests gradually reverted toward control levels, and the delayed absorption pattern characteristic of malabsorption emerged (Figure 4). By January 1964 the patient again complained of bone pain, and the serum calcium had fallen to $8.3 \mathrm{mg}$ per $100 \mathrm{ml}$.

\section{Discussion}

The availability of radioactive isotopes of calcium and of the related alkaline earth, strontium, has stimulated search for improved methods of assessing calcium absorption. To date these have included time-consuming 12 - to 14-day intrave- 
nous isotope infusion studies with indirect calculation of calcium absorption (12-14), cumbersome 4- to 6-day stool radioactive measurements following oral isotope administration $(15,16)$, serial analysis of plasma and urine radioactivity following oral doses of radioactive calcium or strontium (4, 5, 17-19), and more recently, continuous external counting of bone following an oral dose of $\mathrm{Ca}^{47}$ (3). Methods heretofore advanced as "simplified" oral tests of calcium absorption commonly suffer from the lack of sufficiently large normal population studies, the administration of excessively large doses of radioactivity, and a limited number of observations in untreated patients with known disorders of calcium absorption.

The present study indicates that timed serial plasma samples following an oral dose of $\mathrm{Ca}^{47}$ reflect the intestinal ability to absorb dietary calcium. Similar observations have been made in human subjects by Bhandarkar, Bluhm, MacGregor, and Nordin (18), Samachson (4), Jaworski, Brown, Fedoruk, and Seitz (17), and Caniggia, Gennari, Bianchi, and Guideri (19), and in rabbits by Thomas, Litovitz, and Geschickter (20). The rapid rise in plasma radioactivity to peak levels is consistent with the results obtained by others in human beings, in whom maximal plasma radioactivity was observed normally between 1 and 2 hours following oral administration. The consistent peaking of plasma radioactivity at 1 hour observed in the present study may be attributed to the small amount of carrier stable calcium in the oral test dose, resulting in rapid absorption of $\mathrm{Ca}^{47}$.

Two factors other than absorptive mechanisms that could possibly influence plasma $\mathrm{Ca}^{47}$ levels following an oral dose include the specific activity of intestinal calcium during absorption and the size of the miscible "exchangeable" body pool of stable calcium available for the dilution of the absorbed $\mathrm{Ca}^{47}$. Measurements of calcium concentration in gastric juice were not made during the present investigation, but its contribution was considered insignificant since reported levels of fasting gastric juice calcium are exceedingly low (2.0 to $4.5 \mathrm{mg}$ per $100 \mathrm{ml}$ ) (21). Moreover, these levels have been constant despite marked variations in dietary calcium (21) and in serum calcium levels (22). Since the specific activity of the test dose was identical, and since the contribution of stable calcium in the gastric juice may be assumed to be small, fluctuations in the specific activity of the absorbed $\mathrm{Ca}^{47}$ are minimized $\mathrm{It}$ is also unlikely that complete mixing of the oral $\mathrm{Ca}^{47}$ test dose with intestinal juice calcium takes place before absorption. Other investigators have also detected radioactive calcium in the blood 15 to 30 minutes after injection (23) indicating partial absorption in the upper intestinal tract before mixing with the digestive juices secreted into the lower intestine. The narrow range of plasma $\mathrm{Ca}^{47}$ observed in the normal subjects suggests that in fact neither gastric and intestinal juice calcium nor dietary calcium of the preceding day significantly affects the specific activity of the administered $\mathrm{Ca}^{47}$ within the 4-hour test period.

Exchangeable calcium pool estimates have been made by many investigators following intravenous doses of $\mathrm{Ca}^{47}$ or $\mathrm{Ca}^{45}$ using a variety of techniques (13, 14, 24-27). Reported values of large exchangeable calcium pools in Paget's disease (26, 27), metastatic calcification (8), osteomalacia (28), sarcoidosis (25), hyperparathyroidism (26, $29)$, metastatic bone disease $(30,31)$, and of small pools in hypoparathyroidism $(13,26)$ are based on observations made during experiments varying in time from 3 hours to 10 days. Since the rate of decrease in plasma radioactivity following an oral dose of $\mathrm{Ca}^{47}$ may be presumed to be similar to that after the intravenous injection of radioactive calcium, variations in plasma $\mathrm{Ca}^{47}$ following an oral dose must also result from dilutions by the available miscible pool of body calcium. Although several authors have provided exhaustive analysis of calcium "turnover" and pool sizes utilizing polyexponential mathematical expressions, there is remarkably little information on the fate of an intravenous tracer dose of radioactive calcium within the first 1 to 2 hours following its administration and the amount of stable miscible calcium diluting the $\mathrm{Ca}^{47}$ during this period. It is apparent that the size of the rapidly miscible portion of the stable calcium pool varies directly with the amount of exchangeable bone calcium $(24,25)$. However, there is evidence that the rapid decrease in plasma radioactive calcium 1 to 2 hours after its intravenous administration primarily represents mixing with extracellular fluid stable calcium (26). Recent studies in this laboratory on the fate of an intravenous dose of 
TABLE VI

$\mathrm{Ca}^{47}$ content of serum in Paget's disease and metastatic bone disease

\begin{tabular}{|c|c|c|c|c|c|c|c|c|c|c|}
\hline \multirow[b]{2}{*}{ Subject } & \multirow[b]{2}{*}{ Diagnosis } & \multicolumn{7}{|c|}{ Time in minutes after oral dose } & \multirow{2}{*}{$\underset{\mathrm{Ca}^{47}}{\text { urinary }}$} & \multirow[b]{2}{*}{$\mathrm{E}^{*}$} \\
\hline & & 15 & 30 & 45 & 60 & 120 & 180 & 240 & & \\
\hline & & \multicolumn{7}{|c|}{$\%$ administered dose $/ L$ plasma } & $\begin{array}{c}\text { \% admin } \\
\text { istered } \\
\text { dose }\end{array}$ & g \\
\hline W.H. & $\begin{array}{l}\text { Prostatic carcinoma } \\
\text { with osteoblastic bone } \\
\text { metastasis }\end{array}$ & 0.29 & 0.65 & 1.04 & 1.64 & 1.41 & 1.24 & 1.14 & 1.31 & 12.3 \\
\hline J.P. & $\begin{array}{l}\text { Breast carcinoma with } \\
\text { osteolytic bone } \\
\text { metastasis }\end{array}$ & 0.36 & 0.71 & 1.20 & 1.58 & 1.39 & 1.30 & 1.01 & 1.42 & 15.4 \\
\hline W.J. & Paget's disease & 0.47 & 1.25 & 1.51 & 1.74 & 1.28 & 1.05 & 0.94 & 0.72 & 23.0 \\
\hline F.H. & Paget's disease & 0.19 & 0.68 & 0.98 & 1.46 & 0.90 & 0.78 & 0.68 & 0.56 & 19.7 \\
\hline
\end{tabular}

* Total exchangeable calcium pool calculated according to methods of Heaney and Whedon (27).

$\mathrm{Ca}^{47}$ in normal subjects in patients with known disorders of bone confirm this conclusion with close agreement for the first 90 minutes between the calculated calcium content of extracellular fluid and that obtained from the digital computer analysis of isotope disappearance curves (32).

If the plasma levels of $\mathrm{Ca}^{47}$ following an oral dose were significantly influenced by the rapidly miscible calcium pool of bone during the first 90 minutes, one would expect an indirect relationship to obtain between 1-hour plasma $\mathrm{Ca}^{47}$ levels and exchangeable calcium pool sizes. Thus, in metabolic bone disorders characterized by increased miscible pools (vide supra), plasma $\mathrm{Ca}^{47}$ levels would be lower than normal, and in disorders

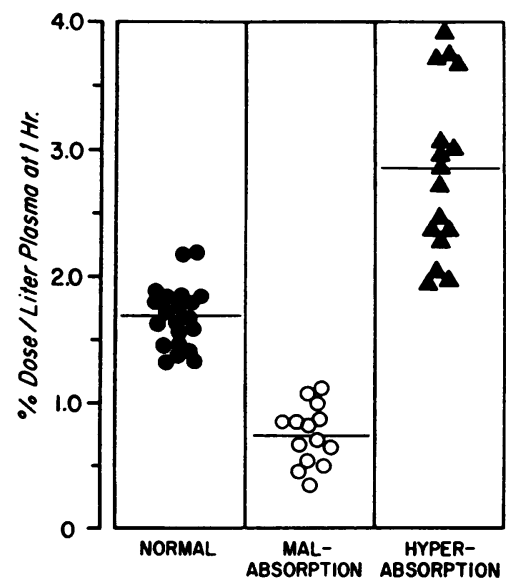

Fig. 5. One-hour plasma Ca ${ }^{47}$ COncentrations in NORMAL SUBJECTS AND IN PATIENTS WITH KNOWN MALABSORPTION OF CALCIUM. The horizontal line in each group represents the mean of the respective population. characterized by decreased calcium pools, higher than normal. The results of the present investigation do not confirm this hypothesis (Tables II and III). In disorders wherein normal or increased miscible calcium pools have been documented (Table II), 1-hour plasma $\mathrm{Ca}^{47}$ levels were high. Moreover, observations in patients with active Paget's disease and metastatic bone disease have revealed normal absorption patterns despite abnormally large exchangeable calcium pools (Table VI). Despite reportedly low exchangeable calcium pools in hypoparathyroidism, plasma $\mathrm{Ca}^{4 \tau}$ values in A.D. were (Table III) consistently low following an oral dose. These latter data are consistent with the observation of malabsorption of calcium in hypoparathyroidism as cited by others $(3,4)$. Thus we concluded that plasma levels of $\mathrm{Ca}^{47}$ during the first 4 hours following oral administration are determined primarily by absorption and are little affected by the exchangeable calcium pool.

A delayed absorption and subsequent plateau in oral absorption curves were characteristic of the malabsorption disorders. This "delayed absorption curve" may reflect differences in intestinal transit time in malabsorption as well as an actual decrease in calcium absorption. Since Thomas and his colleagues observed an identical pattern in rabbits when calcium chelating agents were added to the oral radioactive dose (20), and since identical malabsorptive patterns were observed in the present investigation during sodium phytate administration (Figure 3 and Table V), the ob- 
served malabsorption pattern appears primarily to reflect a decrease in the amount of calcium absorption. Since the pattern of delayed rise in plasma $\mathrm{Ca}^{47}$ at timed intervals following the oral dose is a regular finding in patients with defective calcium absorption, the 4-hour plasma sampling test is recommended in patients suspected of calcium malabsorption. The 1-hour plasma $\mathrm{Ca}^{47}$ content (Figure 5) offers a simplified and reliable alternative in situations precluding multiple venipunctures.

The specificity and sensitivity of the proposed absorption test are illustrated in the serial studies performed in J.D. (Table IV) in whom vitamin $\mathrm{D}$ increased $\mathrm{Ca}^{47}$ absorption, and increasing the calcium content of the diet reduced $\mathrm{Ca}^{47}$ absorption. Nicolaysen, Eeg-Larsen, and Malm (7) and Bronner, Harris, Maletskos, and Benda (15) have previously shown adaptation of the absorptive mechanism to changes in calcium content of the diet in rats and in man, and De Grazia and Rich have also published similar observations made during serial studies in normal volunteers (5).

The calcium intake of the normal subjects varied from 486 to $1,100 \mathrm{mg}$ per day. Only five of those individuals were studied during periods of supervised intake on metabolic weighed diets. The daily calcium intake of the other 16 subjects was either estimated by dietary survey or calculated and ingested without supervision. All the subjects in this group, however, represent individuals with normal gastrointestinal function and normal calcium metabolism who were studied under similar circumstances. A poor correlation between dietary calcium and 1-hour $\mathrm{Ca}^{47}$ levels was observed in these subjects $(r=0.66$, Table I). The reproducibility of the oral $\mathrm{Ca}^{47}$ test in the same individual during a supervised calcium intake protocol was remarkably constant (J.D., B.B., L.P., Table IV). Similar observations in individuals on nonsupervised calcium intakes have been made by De Grazia and Rich (5) and attest to the limited variability of calcium absorption in the same individual. The wide range of 1-hour plasma $\mathrm{Ca}^{47}$ levels in this study (1.31 to 2.19 , Table I) probably reflects differences in age, the production of digestive enzymes, intestinal motility, and numerous other dietary and metabolic factors that normally regulate the intestinal absorption of calcium.
The decreased absorption of $\mathrm{Ca}^{47}$ in J.D. during a period of increased calcium intake is not inconsistent with the observed lack of significant correlation between dietary calcium and 1-hour plasma $\mathrm{Ca}^{47}$ values in the normal population, since this intestinal "adaptation" phenomenon was demonstrated in the same individual during a period of metabolic balance when the only dietary adjustment was that of increasing the calcium content. The reproducibility of the 1 -hour $\mathrm{Ca}^{47}$ values in J.D., over a 6-month period, the decreased values during a period when calcium intake was increased, and the dramatic increment in plasma $\mathrm{Ca}^{47}$ activity during vitamin $\mathrm{D}$ ingestion (Table IV) reflect the value of serial observations in the same individual during a prolonged period of rigid dietary control.

Since there is evidence that calcium absorption is increased when dietary calcium is decreased $(7,33)$, the increments in 1 -hour plasma $\mathrm{Ca}^{47}$ values observed in patients with known disorders of calcium metabolism could possibly reflect intestinal absorption as conditioned by dietary alterations. Twelve of the 17 subjects with "hyperabsorptive" disorders were studied during supervised calcium intake protocols, and no correlation was noted between dietary calcium and 1-hour plasma $\mathrm{Ca}^{47}$ values (Table II). With the exception of B.B. and M.W. (Table II), calcium intake in this group ranged from 400 to $1,020 \mathrm{mg}$ per day, with 13 patients on intakes greater than $500 \mathrm{mg}$.

Similarly, nine of the 14 patients with intestinal malabsorption were studied under metabolic balance conditions (Table III) with intakes ranging from 156 to $500 \mathrm{mg}$ calcium per day. The calcium intake in this group was in general much lower than that of the normal controls (Table I) or those subjects with hyperabsorptive conditions (Table II), and yet the 1-hour plasma $\mathrm{Ca}^{47}$ was significantly depressed. The relative increments in plasma $\mathrm{Ca}^{47}$ in hyperparathyroidism, sarcoidosis, idiopathic hypercalciuria, and calcinosis universalis despite calcium intakes approximating a gram per day, and the decreased plasma $\mathrm{Ca}^{47}$ values in malabsorptive states with relatively low calcium intakes suggest that in these patients the intestinal adaptation phenomenon demonstrated in J.D. is either lacking or overcome by their respective disease process. 


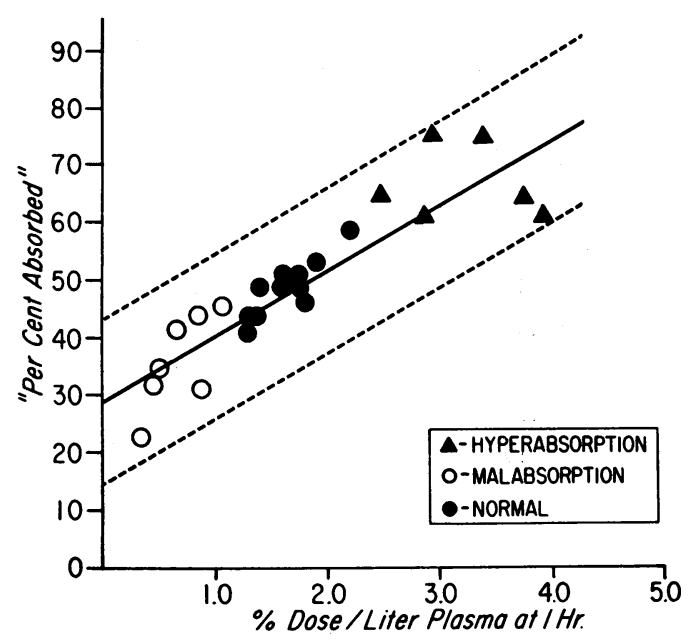

Fig. 6. Relation Between absorption of oral $\mathrm{CA}^{47}$ TEST DOSE AND 1-hour Plasma $\mathrm{CA}^{47}$ activity. The solid line represents the regression line of the net absorption on the plasma activity, and the dotted line, $95 \%$ confidence limits.

Since a negligible fraction of an absorbed calcium tracer is re-excreted into the intestines within 6 days $(11,34)$, and since only negligible amounts of $\mathrm{Ca}^{45}$ (and $\mathrm{Ca}^{47}$ ) are re-excreted in the stools beyond 6 days following administration (15-17, 32 ), it can be assumed that the absorbed radioactive calcium equals the administered $\mathrm{Ca}^{47}$ minus the cumulative 6-day fecal $\mathrm{Ca}^{47}$ excretion. Recent experiments wherein the adequacy of 6-day stool collections was evaluated by the simultaneous administration of nonabsorbable chromium ${ }^{51}$-labeled red blood cells and radioactive calcium suggest that this collection period is adequate for estimating the per cent of oral radioactive calcium absorbed (5). The difference between uncorrected and true absorption (considering endogenously secreted calcium) in this series of 17 patients was always less than 7\% (5). The net absorption of radioactive calcium in normal patients approximated in this fashion agrees well with earlier observations of Brine and Johnston (34) and Bronner and associates (35). In 27 observations herein reported there was a significant correlation $(\mathrm{r}=0.89, \mathrm{p}<0.001$, Figure 6$)$ between the 1-hour $\mathrm{Ca}^{47}$ level and per cent absorption calculated from the 6-day stool collection. This observed correlation in normal subjects and in patients with known disorders of calcium absorption suggests that the proposed test may be used as a reliable index of calcium absorption in man.

\section{Summary}

A simple 4-hour isotope test for in vivo analysis of calcium absorption in man has been evaluated in 21 normal adults, in 14 patients with decreased intestinal absorption, and in 17 patients with disorders characterized by increased calcium absorption. A significant correlation was obtained between 1-hour plasma radioactivity and the per cent of $\mathrm{Ca}^{4 i}$ absorbed during simultaneous cumulative 6-day fecal radioactivity measurements. Normal subjects demonstrate a rapid uptake of $\mathrm{Ca}^{47}$ with maximal plasma values at 1 hour followed by a gradual decline in the subsequent 3-hour period. Patients with malabsorptive disorders demonstrate delayed absorption with lower plasma radioactivity at 1 hour. Abnormal absorption patterns in these patients were restored toward normal by vitamin D. Patients with disorders characterized by increased calcium absorption demonstrated accentuation of the normal pattern. Serial 4-hour oral $\mathrm{Ca}^{47}$ tests in these patients revealed suppression of the increased calcium absorption during sodium phytate therapy.

\section{Acknowledgments}

The authors gratefully acknowledge the assistance of Misses Madeline A. Nowacki and Maureen Sculley. We are also grateful to Mrs. Estelle Saplicki, dietitian, and Mr. James V. Mahoney, medical illustrator, of the Clinical Research Center.

\section{References}

1. Henneman, P. H., E. F. Dempsey, E. L. Carroll, and F. Albright. The cause of hypercalciuria in sarcoid and its treatment with cortisone and sodium phytate. J. clin. Invest. 1956, 35, 1229.

2. Henneman, P. H., P. H. Benedict, A. P. Forbes, and H. R. Dudley. Idiopathic hypercalciuria. New Engl. J. Med. 1958, 259, 1.

3. Lutwak, L., and J. R. Shapiro. Calcium absorption in man: based on large volume liquid scintillation counter studies. Science 1964, 144, 1155.

4. Samachson, J. Plasma values after oral ${ }^{45}$ calcium and ${ }^{85}$ strontium as an index of absorption. Clin. Sci. 1963, 25, 17.

5. De Grazia, J. A., and C. Rich. Studies of intestinal absorption of calcium ${ }^{45}$ in man. Metabolism 1964, 13, 650 .

6. Bronner, F. Dynamics and function of calcium in Mineral Metabolism, C. L. Comar and F. Bronner, Eds. New York, Academic Press, 1964, vol. 2, p. 367. 
7. Nicolaysen, R., N. Eeg-Larsen, and O. J. Malm. Physiology of calcium metabolism. Physiol. Rev. 1953, 33, 424.

8. Henneman, P. H., L. V. Avioli, and J. E. McDonald. Unpublished observations.

9. MacIntyre, I. The flame-spectrometric determination of calcium in biological fluids and an isotopic analysis of the errors in the Kramer-Tisdall procedure. Biochem. J. 1957, 67, 164.

10. Fiske, C. H., and Y. SubbaRow. The colorimetric determination of phosphorus. J. biol. Chem. 1925, 66,375 .

11. Snedecor, G. W. Statistical Methods Applied to Experiments in Agriculture and Biology, 5th ed. Ames, Iowa, Iowa State University Press, 1956.

12. Bronner, F., and R. S. Harris. Absorption and metabolism of calcium in human beings, studied with calcium $^{45}$. Ann. N. Y. Acad. Sci. 1956, 64, 314.

13. Heaney, R. P. Radiocalcium metabolism in disuse osteoporosis in man. Amer. J. Med. 1962, 33, 188.

14. Lazor, M. Z., L. Rosenberg, and P. Carbone. Studies of calcium metabolism in multiple myeloma with calcium $^{4 \tau}$ and metabolic-balance techniques. $\mathrm{J}$. clin. Invest. 1963, 42, 1238.

15. Bronner, F., R. S. Harris, C. J. Maletskos, and C. E. Benda. Studies in calcium metabolism. Effects of food phytates on calcium ${ }^{45}$ in children on lowcalcium breakfasts. J. Nutr. 1954, 54, 523.

16. Blau, M., H. Spencer, J. Swernov, J. Greenberg, and L. Laszlo. Effect of intake level on the utilization and intestinal excretion of calcium in man. J. Nutr. 1957, 61, 507.

17. Jaworski, Z. F., E. M. Brown, S. Fedoruk, and $H$. Seitz. A method for the study of calcium absorption by the human gut using a standard dose of calcium labeled with calcium ${ }^{47}$. New Engl. J. Med. 1963, 269, 1103.

18. Bhandarkar, S. D., M. M. Bluhm, J. MacGregor, and B. E. C. Nordin. Isotope test of calcium absorption. Brit. Med. J. 1961, 2, 1539.

19. Caniggia, A., C. Gennari, V. Bianchi, and R. Guideri. Intestinal absorption of ${ }^{45} \mathrm{Ca}$ in senile osteoporosis. Acta med. scand. 1963, 173, 613.

20. Thomas, R. O., T. A. Litovitz, and C. F. Geschickter. Alterations in dynamics of calcium metabolism by intraintestinal calcium reservoirs. Amer. J. Physiol. 1954, 176, 381.

21. Kirsner, J. B., and J. E. Bryant. The calcium content of gastric juice. Amer. J. dig. Dis. 1939, 6, 704.
22. Val Dez, F. C., and J. Sendroy, Jr. The relationship between gastric acidity and calcium. Amer. J. dig. Dis. 1942, 9, 367.

23. Blau, M., H. Spencer, J. Swernov, and D. Laszlo. Utilization and intestinal secretion of calcium in man. Science 1954, 120, 1029.

24. Rich, C. The distribution of calcium given to human subjects by sustained intravenous infusion. J. clin. Endocr. 1960, 20, 147.

25. Haymovitz, A., and M. Horwith. The miscible calcium pool in metabolic bone disease-in particular, acromegaly. J. clin. Endocr. 1964, 24, 4.

26. Krane, S. M., G. L. Brownell, J. B. Stanbury, and H. Corrigan. The effect of thyroid disease on calcium metabolism in man. J. clin. Invest. 1956, 35, 874.

27. Heaney, R. P., and G. D. Whedon. Radiocalcium studies of bone formation rate in human metabolic bone disease. J. clin. Endocr. 1958, 18, 1246.

28. Fraser, R., M. Harrison, and K. Ibbertson. The rate of calcium turnover in bone. Measurement by tracer test using stable strontium. Quart. J. Med. 1960, 29, 85.

29. Lafferty, F. W., and O. H. Pearson. Skeletal, intestinal and renal calcium dynamics in hyperparathyroidism. J. clin. Endocr. 1963, 23, 891.

30. Corey, K. R., P. Kenny, F. Greenberg, A. Pazianos, O. H. Pearson, and J. S. Laughlin. The use of calcium $^{47}$ in diagnostic studies of patients with bone lesions. Amer. J. Roentgenol. 1961, 85, 955.

31. Avioli, L. V., and T. F. Williams. An evaluation of calcium metabolism in metastatic bone disease. Clin. Res. 1961, 9, 26.

32. Avioli, L. V., and J. McDonald. Unpublished observations.

33. Wasserman, R. H., and C. L. Comar. The parathyroids and the intestinal absorption of calcium, strontium and phosphate ions in the rat. Endocrinology 1961, 69, 1074.

34. Brine, C. L., and F. A. Johnston. Endogenous calcium in the feces of adult man and the amount of calcium absorbed from food. Amer. J. clin. Nutr. 1955, 3, 418.

35. Bronner, F., P. D. Saville, J. A. Nicholas, J. R. Cobb, P. D. Wilson, Jr., and P. D. Wilson. Quantitation of calcium absorption and the excretion index in Radioisotopes and Bone, P. Lacroix, F. C. McLean, and A. M. Budy, Eds. F. A. Davis, 1962, p. 17. 